\title{
Research on Ethnic Regional Economic Development in Southwest China and "One Belt One Road" Strategy -- Take Central Yunnan Economic Zone as an Example
}

\author{
Yu Dejun* \\ (Yunnan College of Business Management, Kuming Yunnan, 650106) \\ *yudejun2004@163.com \\ ${ }^{*}$ The Corresponding Author
}

Keywords: One belt; One road; Regional economy; Central Yunnan Economic Zone; Development strategy

\begin{abstract}
This paper is illustrated by the example of Central Yunnan Economic Zone, and analyzes the factors that affect the economic development of ethnic minorities in Central Yunnan Economic Zone under the background of "One Belt, One Road" strategy, from the aspects of the overall development of the national economy, the industrial structure, the human capital, the foreign trade and the investment in fixed assets. Based on the panel data model, this paper analyzes the influencing factors of the development of Central Yunnan Economic Zone, so as to provide a basis for how to better promote the modernization and sustainable development of Central Yunnan Economic Zone.
\end{abstract}

\section{“One Belt One Road" Strategy and the Economic Zone Development in Central Yunnan}

The "One Belt and One Road" strategy proposes a new pattern of opening up to the ethnic minority areas. Our country has started a full-scale development in the special economic zones, coastal cities and river-running cities. The regional economy which is affected by factors such as the level of regional development presents an unbalanced development trend. The strategy of "One Road" improves the openness of the eastern coastal areas and promotes the all-round development of ethnic minority areas.

\section{Analysis of the Economic Development and Influencing Factors in Yunnan Province.}

The Overall Development of the National Economy. The four major cities in the Yunnan Economic Zone, consisting of Kunming, Qujing, Yuxi and Chuxiong Yi Autonomous Prefecture, are the core areas for promoting the leap-forward economic development in the province. In 2016, the region's total output value reached 78.346 billion yuan, accounting for $58.2 \%$ of the province's total. The permanent resident population in the region was 18.616 million, accounting for $37.9 \%$ of the province's total. The Yunnan Central Economic Zone is one of the 11 key economic zones planned for the "Twelfth Five-year Western Development Plan" and one of the 18 key development zones under the "National Major Functional Areas Planning". Under the strategy of the "One Belt and One Road", the Yunnan Central Economic Zone has more development opportunities than before.

Due to its superior geographical location and resource advantages, the Central Yunnan Economic Zone has become the leader of economic development. Overall, the Yunnan Interlligent Economic Zone enjoys a relative superior economic strength in Yunnan Province, but the distribution of economic strength within the area is not balanced, as shown below. 
Table 1 Economic Indicators of Yunnan Central Economic Zone

\begin{tabular}{llllll}
\hline City indicators & $\begin{array}{l}\text { The total } \\
\text { populatio } \\
\mathrm{n} \\
\text { (million) }\end{array}$ & $\begin{array}{l}\text { Regional } \\
\text { GDP (ten } \\
\text { thousand } \\
\text { yuan) }\end{array}$ & $\begin{array}{l}\text { Per } \\
\text { capita } \\
\text { GDP } \\
\text { (yuan) }\end{array}$ & $\begin{array}{l}\text { Import and } \\
\text { export volume } \\
\text { (million US } \\
\text { dollars) }\end{array}$ & $\begin{array}{l}\text { Financial income } \\
\text { (ten thousand } \\
\text { yuan) }\end{array}$ \\
\hline Kunming & 643.9 & 21203031 & 33549 & 1010928 & 2538319 \\
Qujing & 586.1 & 10055965 & 17228 & 17548 & 724326 \\
Yuxi & 230.6 & 7364354 & 32089 & 28567 & 647297 \\
$\begin{array}{l}\text { Chuxiong } \\
\text { Central }\end{array}$ & 268.7 & 4047301 & 14960 & 10045 & 306979 \\
$\begin{array}{l}\text { Yunnan } \\
\text { Economic }\end{array}$ & 1729.3 & 42670651 & 24675 & 1067088 & 4216921 \\
$\begin{array}{l}\text { Zone } \\
\text { Yunnan }\end{array}$ & & & & & \\
$\begin{array}{l}\text { Province } \\
\text { Central }\end{array}$ & 4601.6 & 72241800 & 15752 & 1336795 & 8711875 \\
$\begin{array}{l}\text { Yunnan / } \\
\text { Yunnan }\end{array}$ & $37.58 \%$ & $59.07 \%$ & $156.65 \%$ & $79.82 \%$ & $48.40 \%$ \\
\hline
\end{tabular}

Note: The sources of data come from the Statistical Yearbook of Si Zhou City in Yunnan Province and the Statistical Yearbook of Yunnan Province.

Industrial Structure and Level of Development. The change of the regional industrial structure is an important indicator of a sound economic development. In recent 10 years, there is a big change of Yunnan's industrial structure. The proportion of primary industry and secondary industry continues to decline, while the proportion of the tertiary industry in 2015 has surpassed the secondary industry, becoming the pillar industry. It shows that in the past two years industrial structure of Yunnan Province is increasingly rationalized, and Yunnan's economic development tends to be healthy.

Human Capital. Human capital is the main driving force for enhancing the vitality of economic development and promoting sustained economic development. As the current domestic economic development has reached a new stage, the role of human capital in economic development is constantly being highlighted. Economic development requires highly qualified personnel. The average wage level in Yunnan Province in the past 10 years is generally in a rising process, indicating that the human capital situation in Yunnan Province is constantly improving. Since 2010, the average wage in Kunming was significantly higher than that in other places of Yunnan Province.

Foreign Trade. The implementation of reform and opening up is the main reason for the rapid economic growth in our country. It can effectively promote the readjustment and upgrading of the industrial structure in the region and enhance the international competitiveness of the regional economy. In 2013, with the development of China's "One Belt and One Road" strategy, Yunnan Province, as a southwestern gateway to China that borders on Southeast Asian countries, should play an increasingly important role in foreign trade.

Table 2 shows that the import and export volume of Kunming has been declining rapidly in recent years. It shows that the economic development of Kunming is increasingly dependent on domestic consumption in recent years and the regional economic development is reducing the dependence on neighboring countries. In the other three cities, import and export volume is on the rise in recent years, but its growth rate is relatively slow. 
Table 2 Total import and export volume in Central Yunnan (100 million U.S. dollars)

\begin{tabular}{llllll}
\hline city & Trade type & 2013 & 2014 & 2015 & 2016 \\
\hline \multirow{3}{*}{ Kunming } & import and export & 174.22 & 177.87 & 123.64 & 66.81 \\
& Export & 104.1 & 116.07 & 94.54 & 41.33 \\
& import & 70.12 & 61.79 & 29.1 & 25.48 \\
\multirow{5}{*}{ Qujing } & import and export & 3.71 & 4.47 & 5.6 & 6.3 \\
& Export & 3.35 & 4.39 & 5.44 & 6.27 \\
& import & 0.36 & 0.08 & 0.16 & 0.03 \\
\multirow{4}{*}{ Yuxi } & import and export & 7.14 & 9.69 & 18.96 & 20.2 \\
& Export & 6.79 & 9.13 & 18.52 & 19.92 \\
& import & 0.35 & 0.56 & 0.44 & 0.27 \\
\multirow{3}{*}{ Chuxiong } & import and export & 2.8 & 3.34 & 4.32 & 5.1 \\
& Export & 2.56 & 3.33 & 4.32 & 5.08 \\
& import & 0.24 & 0 & 0.001 & 0.29 \\
\hline
\end{tabular}

Note: The data source is from the Statistical Yearbook of Si Zhou City in Central Yunnan.

Investment in Fixed Assets. To a certain extent, the investment in fixed assets can directly increase the output of the economy, which can have a direct impact on economic development and thus form a different level of economic development. The rising of the investment in fixed assets in Yunnan Province during the past 10 years shows that the infrastructure conditions for economic development in Yunnan Province have continued to improve.

\section{The Factor Analysis what the Empirical of the economic Development in Yunnan Economic Zone.}

Variable Selection. The author found that the development of Kunming is superior to that of the other three cities in Central Yunnan. In order to find out to what extent the factors mentioned in the preceding paragraph have unbalanced the development of Central Yunnan, the author analyzes the economic development data of four prefectures and cities in central Yunnan. Where, let y be the per capita GDP, $x_{1}$ represents the added value of the secondary industry per capita, $x_{2}$ represents the added value of the tertiary industry per capita, $\mathrm{x}_{3}$ represents the per capita investment in fixed assets, $\mathrm{x}_{4}$ represents the total amount of imports per capita, and $\mathrm{x}_{5}$ represents the average wage.

Variable Balance Test. After taking the logarithm of all the variables, The result of balance test can be obtained, and whether the set variables can still maintain the balance after logarithm can be determined, so as to provide basis for model building. After Levin-Lin-Chu and Im-Pesaran-Shin unit root tests, it is found that the logarithms of all variables were 0.0000 for Levin-Lin-Chu and Im-Pesaran-Shin test, indicating that the variables were well balanced.

The Determination of Panel Data Model and Form. The model is commonly referred to as the panel data model, the author will use the panel data of four prefectures in central Yunnan to analyze the factors which affect the development of central Yunnan. The equation of the model is as follows:

$$
y_{i t}=\alpha_{i}+x_{i t} \beta_{i}+\mu_{i t}, i=1,2,3 . . ; t=1,2,3 . . T
$$

In the model, yit is the dependent variable, which represents the gross national product per capita in central Yunnan, $\alpha$ it is the intercept, xit and $\beta$ it are the column vectors, and uit is the random variable. According to the research needs of this article, the model is improved and the following model is built:

$$
\ln y_{i t}=\alpha_{i}+\beta_{\mathbf{1}} \ln x_{1 i t}+\beta_{\mathbf{2}} \ln x_{2 i t}+\beta_{\mathbf{3}} \ln x_{\mathbf{3}}+\beta_{\mathbf{4}} \ln x_{\mathbf{4}}+\beta_{\mathbf{5}} \ln x_{\mathbf{5}}+\mu_{i t}
$$

Where $\mathrm{i}=1,2,3 ; \mathrm{t}=1,2,3 \ldots 12$, ai is used to describe the difference caused by different objects, $\mathrm{y}$ is GDP per capita, $\mathrm{x} 1$ is the added value of secondary industry per capita, $\mathrm{x} 2$ Said per capita tertiary industry added value, $\mathrm{x} 3$ said per capita investment in fixed assets, $\mathrm{x} 4$ said the total amount of imports per capita, $\mathrm{x} 5$ said the average wage.

Analysis of Data Processing and Impact. The data was applied to the model and Eviews software was used for data processing, following results were obtained as shown in Table 3. 
Table 3 Results

\begin{tabular}{l|l|l|l|l}
\hline Explanatory variables & $\beta$ & Standard deviation & The value of $\mathrm{t}$ & Prob. \\
\hline $\mathrm{C}$ & 0.224653 & 0.047563 & 4.936424 & 0.0000 \\
$\ln \mathrm{X}_{1}$ & 0.385876 & 0.037624 & 13.57353 & 0.0000 \\
$\ln \mathrm{X}_{2}$ & 0.537563 & 0.053425 & 11.44756 & 0.0000 \\
$\ln _{3}$ & 0.004762 & 0.011545 & 0.268353 & 0.7463 \\
$\ln \mathrm{X}_{4}$ & -0.08465 & 0.016452 & -4.76543 & 0.0000 \\
$\ln \mathrm{X}_{5}$ & 0.174575 & 0.046255 & 7.846573 & 0.0674 \\
\hline Fixed Effects(Cross) & -0.0224543 \\
\hline BJ-C & -0.0248362 \\
TJ-C & -0.0435424 & \\
HB-C & D-W & \\
\hline R-squared & Prob(F-statistic) \\
F-statistic & 0.999364 & 1.736524 \\
\hline
\end{tabular}

The results of model data processing showed that the R-squared value was 0.999364 and the $\mathrm{D}-\mathrm{W}$ value was 1.736524 . By P-value test, one of the variables selected did not pass the test, and the significant level did not reach $10 \%$. Overall, the results of the model processing can explain the economic development in Central Yunnan Province.

The results in Table 3 show that the added value of the tertiary industry per capita, fixed asset investment per capita, average wage and other four factors have a positive impact on GDP per capita in central Yunnan. Among them, the added value of the tertiary industry per capita exerts the most obvious impact, followed by the added value of the secondary industry per capita. Although the proportion of the secondary industry has been declining in recent years, its contribution to economic development is still indelible. Technology innovation should be given top priority so as to promote the industrial renovation in this region, so as the average wage level. High-quality human resources can effectively ensure sustainable economic development.

\section{Conclusion and Countermeasures}

Strategic positioning of Yunnan Central Economic Zone: An important regional international transportation hub, China's southwestern portal, national key industrial and agricultural base, the industrial transfer base, export processing base. Development Goals: Scientific Development, Harmonious Development and Leap-over Development. The overall layout: Kunming as the center, with Qujing, Yuxi, Chuxiong and other cities as the main transport hub of the support link to promote the healthy development of economic zone in Yunnan.

Foster a New Type of Industrialization and Agricultural Industrialization. We will promote the optimization and upgrading of the industrial structure in Yunnan's economic zone through new-type industrialization, vigorously develop the characteristics of plateau eco-agriculture, readjust production quality, speed up industrial restructuring and upgrading, and promote the development of the service industry.

Promote Urban-rural Economic and Social Integration. Economic and social integration of urban and rural areas should be taken as the fundamental requirement to speed up the "six integration" of Yunnan's economic zone. First, accelerate the integration of urban and rural planning; second, speed up the integration of urban and rural industries; third, speed up the integration of urban and rural resources; fourth, speed up the integration of urban and rural employment; fifth, speed up the integration of urban and rural infrastructure; sixth, speed up the integration of urban and rural public finances and public services. 


\section{References}

[1] Zhang Junwen. Research Report on Building Financial Support in Central Yunnan New Area Based on the Analysis of the Core Areas of Songming [J]. Times Finance, 2015 (23).

[2] Wang Dingbao. Qujing docking "Belt and Road" strategy development path [J]. Urban and Rural Construction, 2016 (5): 63-64.

[3] Yunnan Bureau of Statistics. 2012 Yunnan Statistical Yearbook [J]. 2012.

[4] Quiet. Portal and hub of Yunnan in the west to open the position and role [J]. Guangming Daily 11 Edition: Famous Bright Forum, 2015.

[5] Zheng Baohua. Building an Industrial New District in Yunnan as an Engine for a Strong Industrial Province [J]. Socialism Forum, 2013 (4): 13-14. 